\title{
BCG IMMUNOTHERAPY FOR MALIGNANT MELANOMA OF THE NOSE AND PARANASAL SINUSES
}

\author{
HISAKI SAITO, M. D., JIRO HOZAWA, M. D., MASAAKI KASAHARA, M. D. \\ AKIKO TAKAGI, M.D. AND MASAO NAGAI, M.D.
}

Department of Otorhinolaryngology, Hirosaki University, School of Medicine, Hirosaki

(Director: J. Hozawa, M. D.)

Seven patients with malignant melanoma in the nasal cavity and paranasal sinuses were treated with BCG immunotherapy in authors clinic during 3 years from September, 1976 to November, 1979.

In case 1 (stage IV) and case 2(stage IV), BCG was injected into the tumor tissue with combination of ${ }^{60} \mathrm{Co}$ irradiation. The treatment was ineffective for case 1 , who died after 4 months. It appeared to be effective for case 2, who eventually died after 10 months.

Other cases were treated with BCG enterosoluble capsule (per orally $80 \mathrm{mg} / \mathrm{w}$ ) for 5 to 13 months. In case 3 (stage II), and case 6 (stage I), good results were obtained for the prevention of postoperative recurrences. In case 5 (stage IV), a diminution of a metastatic tumor in the lung was observed after administration of BCG capsule. In case 4 (stage II) and case 5, a diminution of metastatic tumors in the skin, lung and brain was observed after administration of BCG capsule combined with DTIC injection. In case 7 (stage IV), a slight growing of a metastatic tumor in the lung was observed during administration of BCG capsule.

$B C G$ enterosoluble capsule may be used for a long time, for the enhancement of the effect of BCG immunotherapy, since non or minimal side effect has been noted.

\section{A $83-0647-30365$}

\section{鼻副鼻腔悪性黑色腫の BCG 療法}

一一特に BCG 腸溶力プセル経ロ投与について—

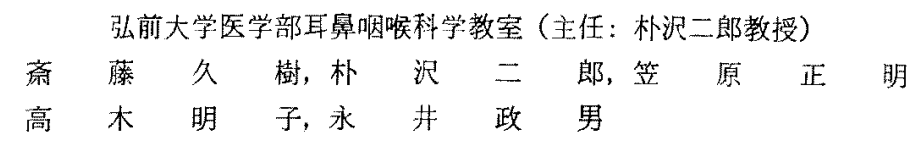

\section{I 緒 言}

覀性黑色腫進展例の治療法上して, 1970年に Morton $5^{1)}$ は， BCG 腫瘍内江接種し，8例中 5 例の有効例を 報告した。 .た，1973年に Falk ら² 投与老反復し， 7 例中 5 例の有効例安報告した。 われわ れは，1976年9月から鼻副鼻腔悪性黒色腫症例火 BCG 療法を行って和り，BCG を腫瘍内に接種した2 例につ

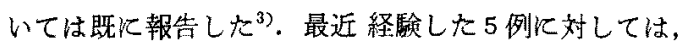

BCG t腸溶カプセルの形で経口投与しているが，手術 可能例偟対しては再発転移の抑制, 進展例飞対しては転 移巣の縮小，臨床症状の改善なと，治療成緹の向上飞役 立っていると思われたのて，若干の文献的検討を加总て 報告する。

\section{II 方 法}

材料は，日本 $\mathrm{BCG}$ 研究所製 living BCG（一部は厚 


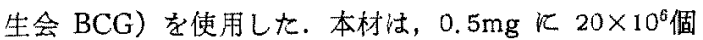
の細菌数を含む。包装仗， $5 \mathrm{mg}, 40 \mathrm{mg}, 80 \mathrm{mg}$ のアンプ

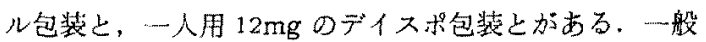

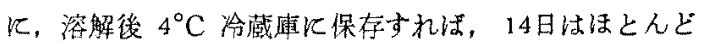
力価は落ちないといわれている4)が，われわれは，投与 法にかか和りなく, 開封後出来るだ早期飞使用した。 な招, 経口投与の場合, 主飞 $80 \mathrm{mg}$ の包装を使用し, 胃 酸による生菌数の減少を防くために腸溶カプセル内に封 入して空腹時に投与した。腸溶カプセルは，ミドリ十字 社から提供を受けた 1 号空力プセルを使用し, 乾燥した ままの BCG 生菌末を調材用マイクロスパーテル等を用 いてカプセル内に封入し，力プセルの接合部には，腸溶

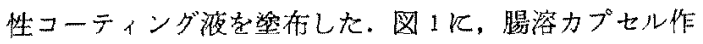
製時飞用いた材料を示す。な挍，この方式の腸溶性コ一 ティングカプセルを内服すると, 患者の胃括よび腸では どの上ろになるかを検討するために，BCG のかわりに バリウム末を腸溶力プセル内に封入して、BCG 投与中 の患者 3 例飞服用（1 例は 2 回, 他は 1 回）させ, 継時 的に X線写真を摄影してカプセルの变化を追求した結 果，胃内で流形のまま保存されて扣り，投与後 1 時間

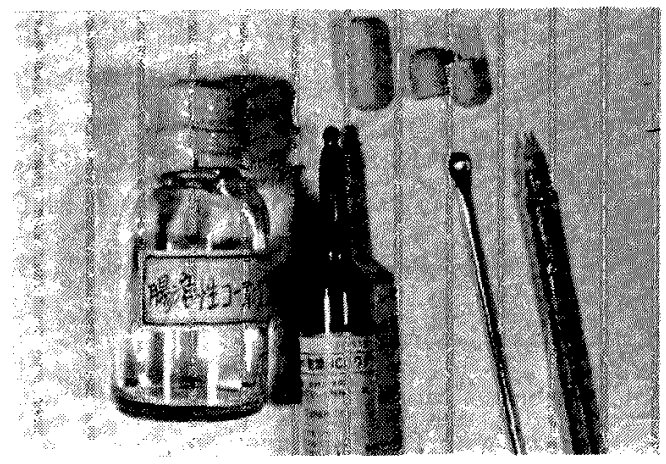

図1 $1 \mathrm{BCG}$ 生菌末を腸溶カプセル飞封入する 際の村料

以内に小腸飞移行し，晹内に移ったカプセルは，投与後 2 時間以上 5 時間以内に小腸内で崩罗することを確認し た. カプセルの崩壊には，野田 ${ }^{5)} の$ 報告よりる長時間を 要した. 図 2 に典型例を示す。

\section{III 諚例}

BCG 療法を行った 7 症例の内訳を表に示す。年略は

表 1 BCG 療法を行った鼻副舅空覀性黒色腫症例

1976.9. 1979. 11. 弘前大耳鼻科

\begin{tabular}{|c|c|c|c|c|c|c|c|c|c|c|c|c|}
\hline \multirow{3}{*}{$\begin{array}{c}\text { No. } \\
1^{*}\end{array}$} & \multirow{3}{*}{$\begin{array}{l}\text { 年 } \\
\text { 粰 } \\
\end{array}$} & \multirow{2}{*}{\multicolumn{3}{|c|}{ 性 Stage 原発果 }} & \multirow[b]{2}{*}{ 転 移 } & \multicolumn{4}{|c|}{ BCG 療法 } & \multirow[b]{2}{*}{ 併用療法 } & \multirow[b]{2}{*}{ BCG 投与後の経過並びK予後 } & \multirow[b]{2}{*}{ 効果 } \\
\hline & & & & & & 方法 & 回 & 総量 & 副作用 & & & \\
\hline & & 女 & N & 左轒胎 & 游, 皮 & $\begin{array}{l}\text { 貼布 } \\
\text { 局注 }\end{array}$ & $\begin{array}{l}1 \\
3\end{array}$ & $\begin{array}{l}40 \mathrm{mg} \\
50 \mathrm{mg}\end{array}$ & $\begin{array}{l}\text { インフ } \\
\text { ルエン } \\
\text { ザ症状 }\end{array}$ & $\begin{array}{l}\text { 暼, 化, } \\
\text { 至 }\end{array}$ & 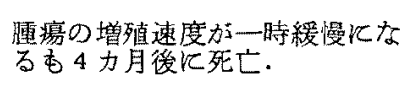 & 無効 \\
\hline $2^{*}$ & 79 & 女 & $\mathbb{N}$ & $\begin{array}{l}\text { 左鼻副 } \\
\text { 累侄 }\end{array}$ & 肺 & $\begin{array}{l}\text { 貼布 } \\
\text { 注 }\end{array}$ & $\begin{array}{l}1 \\
3\end{array}$ & $\begin{array}{l}40 \\
60\end{array}$ & - & 放, 免 & $\begin{array}{l}{ }^{60} \mathrm{C}_{0} \text { 照射との併用にて腫窝の縮 } \\
\text { 小著明. 10力後に死亡. }\end{array}$ & 有効 \\
\hline 3 & 60 & 男 & II & 右鬼腔 & リンパ & $\begin{array}{l}\text { 内服 } \\
\text { 経皮 }\end{array}$ & $\begin{array}{r}57 \\
5\end{array}$ & $\begin{array}{r}4,240 \\
60\end{array}$ & - & $\begin{array}{l}\text { 手, 凍, } \\
\text { 笅, 华, } \\
\text { 食 }\end{array}$ & 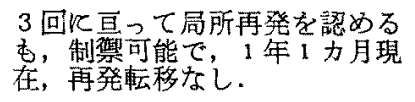 & $\begin{array}{l}\text { 中 } \\
\text { 有効 }\end{array}$ \\
\hline 4 & 41 & 男 & II & 右與腔 & & $\begin{array}{l}\text { 内服 } \\
\text { 経皮 }\end{array}$ & $\begin{array}{l}39 \\
11\end{array}$ & $\begin{array}{r}3,120 \\
132\end{array}$ & - & $\begin{array}{l}\text { 手, 凍, } \\
\text { 货, }\end{array}$ & 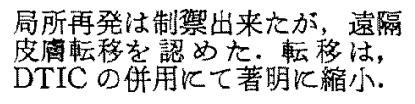 & $\begin{array}{l}\text { P中 } \\
\text { 有効 }\end{array}$ \\
\hline 5 & 55 & 女 & N & 左鼻腔 & $\begin{array}{l}\text { 肺, 脸, } \\
\text { 腹怔, } \\
\text { 皮 }\end{array}$ & $\begin{array}{l}\text { 内服 } \\
\text { 経皮 }\end{array}$ & $\begin{array}{r}34 \\
5\end{array}$ & $\begin{array}{r}2,700 \\
60\end{array}$ & & 华, 免, & 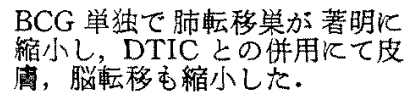 & 有効 \\
\hline 6 & 70 & 男 & 1 & 左覺腔 & & 内服 & 27 & 2,160 & - & 手, 凍, & 術後 6 力月間再発なし. & $\begin{array}{l}\text { Pp } \\
\text { 有效 }\end{array}$ \\
\hline 7 & 60 & 女 & N & 左齄腔 & 肺 & 内服 & 23 & 1,840 & - & 免, 食 & $\begin{array}{l}\text { 臬賞症状皆無であるが，肺転移 } \\
\text { 予定 }\end{array}$ & 不明 \\
\hline
\end{tabular}

* 既発表症例 手: 摘出手術, 凍: 凍結手郝, 放: 放射線痖法, 化: 化学療法, 兔: 兔疫療法 食：低フェニルアラニンチロシン食 


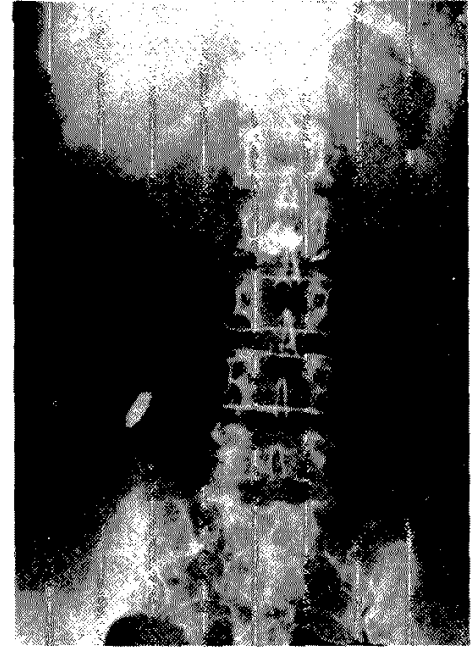

図 2 パリウム腸溶カプセル服用後 3 時間の腹 部単純 X線麦真で，力プセルは3 個とも盟 外飞送出し，少崩壊怙よび中崩罱した2 個 のカプセルが腹部右側に認められる。大塴 壊している1個（第 2 腰椎と重なって認め られる）は，バリウムを腸溶カプセルに入 れたが，カプセルの接合部に腸溶性コーテ ヘング液を塗布しなかったものである。

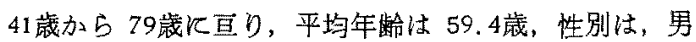
3，女 4 であった. Stage は, BCG 潦法用始時の臨床 病期を示し. 分類に当っては，UICC 第 3 版の皮票悪性

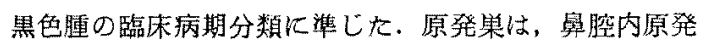

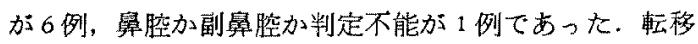

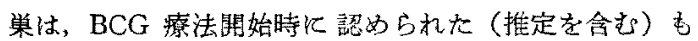
のて，リンパ節，皮萠，脳，肺，腹腔内䑏器等であっ た，なお，経過中红症例 2 は全身転移，䇥例4は遠隔皮

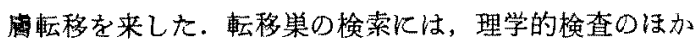
K ${ }^{87} \mathrm{Ga}$ scann, CT-scann を併用している. BCG の投

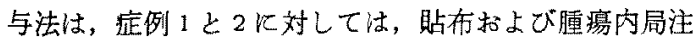
を行い, 症例 3から7までは BCG 晹溶力プセルの経口 投与を基本とし，随時，BCG の経皮接種を併用した. $\mathrm{BCG}$ の経口投与は，症例 3 の安全を期して最初の3 回を1回量40mgず週1回，次の3回孝1国量 $80 \mathrm{mg}$ ずつ過 1 回，生理食塩水に溶解して空腹時飞常水と共に 服用させ，引き続き $\mathrm{BCG}$ 腸溶力プセルの経口投与を行 った. 腸溶力プセルは, 最初の 2 回を 40mg ずつ投与 し，副作用を諗めなかったので以後はすべて1回量 80 mgずつ, 遇1回投与とし, 他の症例書これにならった。 経口投与総䊆は，1979年11月末現在，最大 4,240mg，

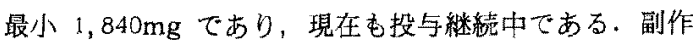
用は，腄㾤内局注を行った症例 1 K，激しい悪寒戦傈之 発警を認めた。経口投与を行った5例飞は，11月末現在で は副作用を証めな加ったが，症例 3 は 12 月上旬化 BCG の副作用加局所感染化よるすの加不明の発就を認め大の て，投与閏隔を延長した。併用療法として，Stage I， II

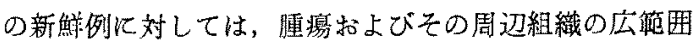
摘出術，患側钼部リンバ節の治療的または予防的郭清， 凍結手術，低フェニルアラニンチロジン食到による食慨 痖法を基本方針として，症例 3 飞は SSM皮下注(AB法。 BB法)，PSK 3g/日 内服 14週間， DTIC (dimethyl triazeno imidazole carboxamide) $100 \mathrm{mg} /$ 日 静注 5 日 閶を併用し，症例 4 亿は，PSK $3 \mathrm{~g} /$ 日 内服 17 造間， DTIC $100 \mathrm{mg} /$ 日 静注 10 日間, FT-207 $800 \mathrm{mg} /$ 内服11 週間老併用した. Stage N D 4 例中症例 5 と 7 江，青

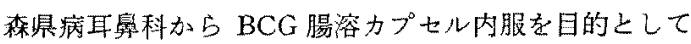
紹介されてきたものて，当科初晾時，症例 5 は術後 2 年, 症例 7 は術後 2 年 4 力月経過して扣り，局所はよく制䇠 されていた，併用噔法として2例とも食䬣療法を行い， 证例 5 は PSK $3 \mathrm{~g} /$ 日 内服 10 週間, DTIC $100 \mathrm{mg} /$ 日 静拄 10 日間を施行し，症例 7 には，OK-4323.0KE/週 筋注を23週間施行した. 経過括よび予後は表のごとく

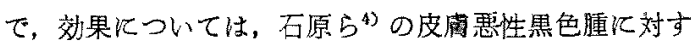
る判定基準を参考汇して，有効，中p有効，無効，扣上 び不明の 4 つに判定した。症例 1 は，SSM 战よび BCG 投与後，I時，腫場の增殖速度が緩慢になったかに見え たのみで，BCG 投与閒始㣪 4 力月目氏死亡したので無 効とした，症例 2 は， ${ }^{60} \mathrm{Co}$ 照射との併用飞て著明な腫痬 の縮小を認めたためやや有効上したが，宽解退院後，遠 隔地执よび老橴を理由として再受彰せず，BCG 投与後 10力月日に死亡した。症例 3 は, 初回手術後の経過中に 奥腔粘膜に小照点の出現と消裉とをくりかえしたこと， 術後 1 年 1 力月現在，小手術等にて制徱可能の局所再発 しか認めなかったことからやp有效とした。症例 4 は, 初回手術時に上咽頭粘膜に腫演の䕗残を認めた例で，街 後の局所再発に対して，右前頭洞へのキリアン氏手術， 上咽頭への凍結手街を追加し，以後，局所再発は認めな 加たが，BCG 投与開始後4力月目飞左拇趾，右下腿 に遠隔転移を゙認めた。酒移果は，DTICの静注を併用後 著明飞縮小し，BCG 投与開始後 9 力月現在, 寛解状態 を維持して外来通院中であるのでや有効とした，鿊例 5 は，当科受部前K，PSK 内服，SSM 皮下注等老批行 したが無教で，OK-432 は，発熱等の副作用が强く，投 
与を継続出来なかった例で， BCG 経口投与と食䬣療法 のみにて食钦が增し，末梢血リンパ球数の增加を諗め，

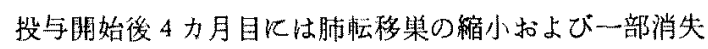
を認め大。引き続き DTIC の静注を併用して，肺転移

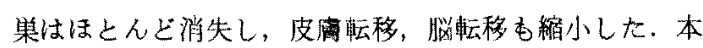
症例は有効上判定した. 症例 6 は, BCG 投与後 6 力月 再発転移を認めないのてやや有効とした、症例 7 は，自 觉症状㫮無で, BCG 投与後 5 力月間通常の勤務を続け ていたが，肺転移果は少し增大傾向を認めるので，近日 中保 DTIC 併用予定である。本症例㹥効果不明とした。

図3に症例 3 の初回手術時（1978．11，8）の摘出㯲 本を示す。な扔，病理組織眐本の細胞型は，紡鐩細胞型 を示していた。

図 4 は, 症例 5 の臨床経過で，BCG 腸溶カプセル経 口投与開始後 1 力月前後から末梢血リンバ球数が增加

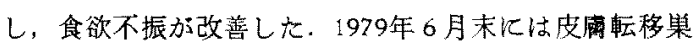
が少し增大し，数も增加した，7月末加，末梢血リン 八球数，PPD 皮内反応発赤経の增大と要下，胸部X

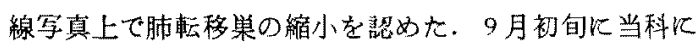
入院し，BCGワタチンの管針法に上る経皮按種，DTIC の静注, PSK の内服を併用した. 末梢血りンパ球数は, DTIC 併用時に一過性に低下したが間もなく回復した。

9 月末には皮転移单毛稚小し，11月21日の CT-scann

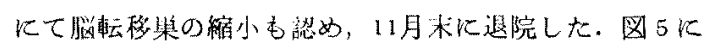

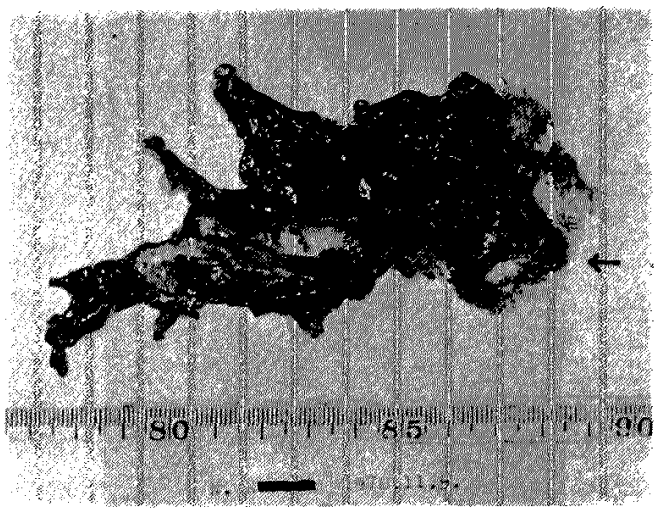

図 3 症例 3 の初回手術時の摘出標本. 矢印の 部分は舅中隔前端示す。左下方の下鼻甲 介，中鼻甲介の一部に白い部分在残すのみ で，ほとんどの右固有鼻腔粘膜は黒色汇着

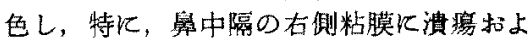
び腫瘤形成が著明である。本例は，他飞， 右上顎洞，䈃骨洞，蝶形骨洞，および，舅 中隔の左側粘膜にも黒い着色を䜑めた。

症例 5 の, 当科初診時, BCG 投与開始後 4 力月半, 招

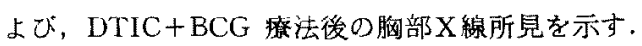

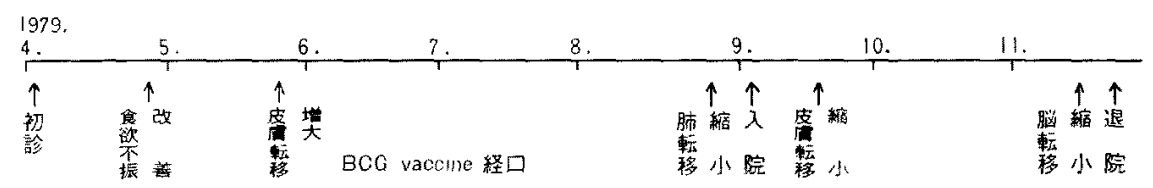

0000000000000000000000000000000000

80
$\mathrm{mig}$ total $2.720 \mathrm{mg}$

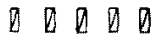

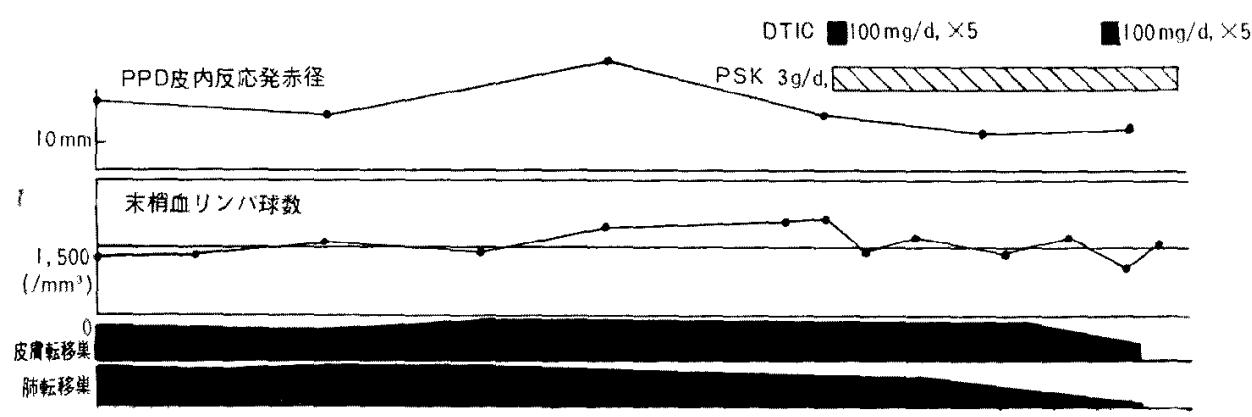

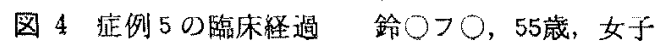



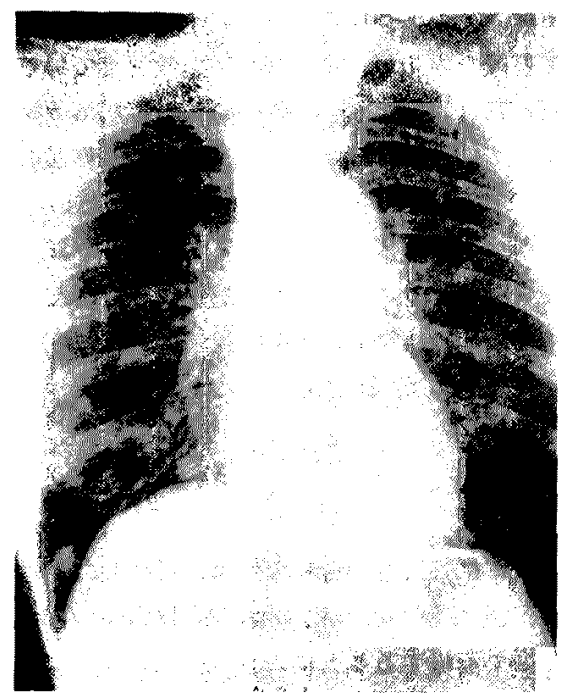

1979. 4. 2.

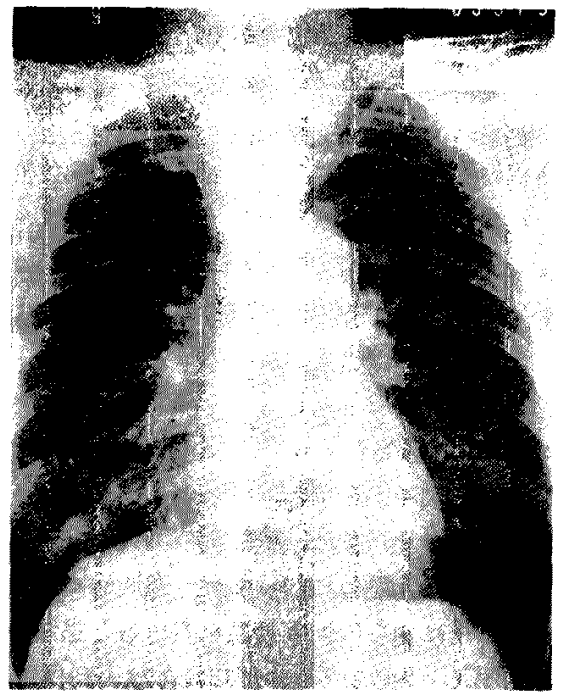

1979. 11. 12.

\section{N 考 按}

1. $\mathrm{BCG}$ の投与法について

BCG の臨床的な投与法としては，1）患者の正常皮 清入接種する方法，2）固仅腫瘤内一注射する力法，3） 四瘍細胞亡 BCG乞の混液を皮内接種す方方法，4）経

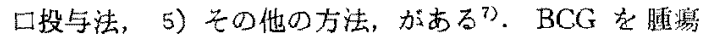

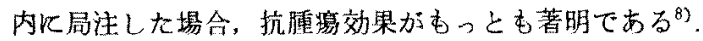
が，副作用娄最毛强く”，われわれも，激しいインフル エンザ様症状を呈した1例を経験した。頭鲌部腫瘍に対

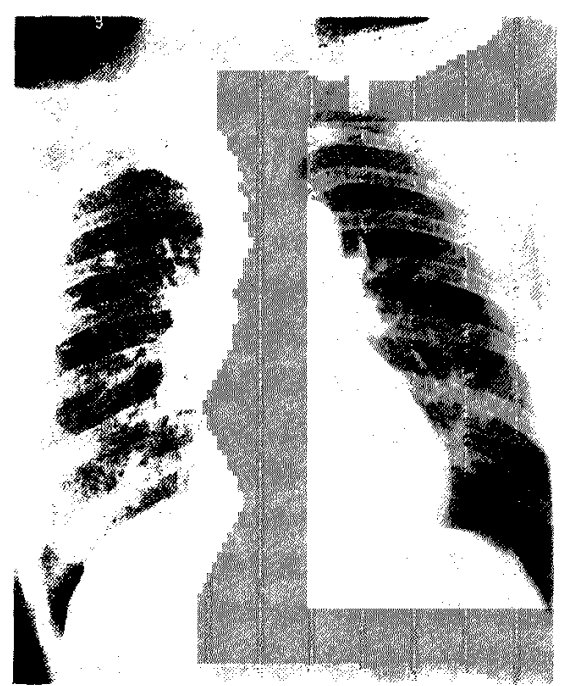

1979. 8. 26.

图 5 上不：症例 5 の当科初款時の胸部 $\mathrm{X}$ 線与

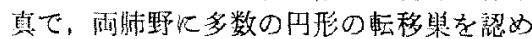
万.

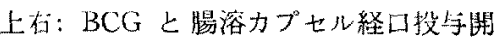
始後 4 力月半経過した際の所見で, 雨肺野 の䎐移笨蛨小し，一部消失している。

下左: DTIC + BCG 療法後の所見で, 闲肺野の耺移巣は一部を残してほとえど消 失している。

するBCGの接与法の一つとして，高橋ら ${ }^{103}$ 隹，局所貼 布を行い，腆湜内注入より屯副作用は少なかったと報告 している.

2. BCG の経口投与について

BCG の経口投与は，特にヨーロッパよブラジルとに

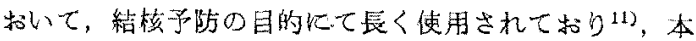

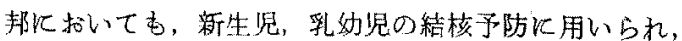
BCG 経口投与でも，\%ヘルクリンアレルギーに感作さ

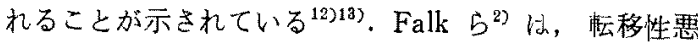


性埋色琏 7 例飞 BCG 経口投与を反復し， 5 例の有効例 を報告し，引き続き，M acGregor $5^{11)}$ は，47例の各

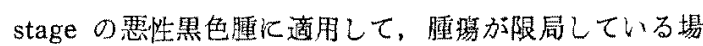
合には，BCG 経口投与は，局所再発括よび遠隔枟移を 遲らせるよ万に思え，播種性の例でも，頭蓋内転移のな

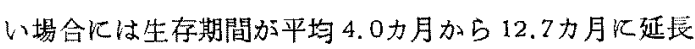

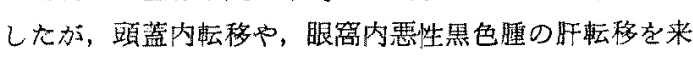
した患者には然効であったと報告した. 石原らすも，

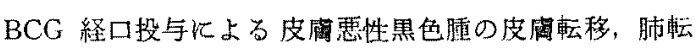
移の縮小を報告している.

德永 $5^{8)}$ 飞よ机ば、BCG を経口投与すると大部分は 胃酸によってて殺菌されるが，少数は腸管に入りパイエル 板に達する。䦪間膜りンパ腺にまで達することは少なく，

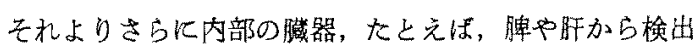
されることはほ上んどないといろ。一方，室橋ら ${ }^{14} は ，$ BCG 経口接種モルモットに扔いて，蔵器からの還元培 養は，腸管から吸収された BCGがかなり急速に遠隔 藏器に撒布されることを示し，気管りンパ䣄などでも， 接種後の比较的早い時期にリンパ節の明らかな腫脹を伴 なって多数のBCGが検出されたという，病理学的所見 として德永 ${ }^{8} は$ ，パイエル板に持けるT，B リンパ球の 強い增殖上マクロファージの著明な浸閏を举げて掠 り，正常動物に結核様病变を惹起することはないとい

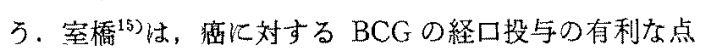
として, 消化管の特色である防衛, 選択, 消化, 吸収, 排除なとの巧妙な機能を利用して，きわめて自然消化 管関連リンパ系に BCGを直接送り込むことができ， し かも非経口投与とは莲って, 皮周への損甥やその他の全 身的副作用を与えることなしに，長期間反復して継続投 与出来ることを挙げている，BCG は生菌ワクチンであ り、投与経路にかかわらず生菌数を低下させないように 注意する必要がある。 BCG の経口投与は一般には， BCG を溶解してそのまま経口摄取させる方法が行われ て括り，石原 ${ }^{16)}$ は，原則的用法として，1 回量老 $80 \mathrm{mg}$ とし，過１回上り始め，兔庭学的パラメーターを見なが ら，2 週に1回あるいは 4 週に1回上するとし，また， 投与上の注意として，ワクチン稀釈にシュース等の酸性 度の高いものをさけ，中性に近い牛乳，湯さまし，番茶， 生食液などのさめたものに混して与えると述でている。

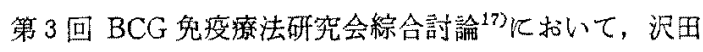
は， $\mathrm{BCG}$ を酸性ジュース，人工胃液など浮遊させる と生菌数はきわめて短時間で 1/4 1/5 以下となるので 腸溶力プセルか何か、入れて领ませるのが良いと述へ，
㙁田は，アルミニウムゲルの乳郕 $50 \mathrm{~m} l$ ほどを食間に与 えて罱酸を中和し，すぐ BCG 老飲ませているという。 われわれは，BCG 乾燥粉末のまま腸溶力プセル内に 封入して経口投与しているが，カプセル作製直後很用 させているため, 多数例への投与山難加しい，日本BCG 研究所火括いては，BCG 腸溶力プセルの武作が行かれ

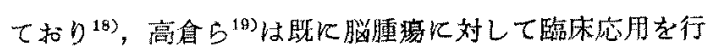
つて括り，近い将来，治験綮上しての供給が期待され る.徉来, $\mathrm{BCG}$ 経口投与による副作用はほとんどない

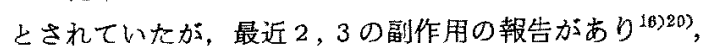
投与量の問題も含めて, 今後さら飞検討が必要と思われ る.

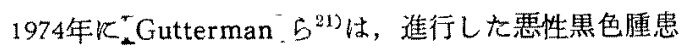
者を, BCG 療法之, 化学療法剂 DTIC の静注とを組み 合わせて治療することにより治痖成績の向上をみたと報 告して扣り，われわれも，進展例任忘用して良い成績を 得ている。な㧊, DTIC+BCG療法については，次の機 会倍しく報告する予定である。

\section{結語}

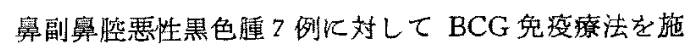
行し，次のような結果を得た。

1. BCG 老腫瑝内に局注した2例中 1 例は副作用な $く,{ }^{60} \mathrm{Co}$ 照射との併用にて腫場の著明な縮小を認めた が，他の1例証局注 2 回目に激しいインフルメンザ症状 老経験した。

2. BCG 腸溶カプセルの 経口投与を行った 5 例中 1 例は肺秐移の縮小を珰め, 残りの4 例も, 局所再発, 遠

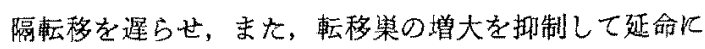
役立っていると思われた．また，進展例に対するDTIC 静注の併用はさらに治療効果を高めると思われた.

3. BCG 腸溶カプセル経口投与は，副作用がほとん どなく、くりか无して反復投与してBCGitis ${ }^{22)}$ を持綕さ せることが出来るので，鼻副鼻腔悪性黒色腫の stage I，

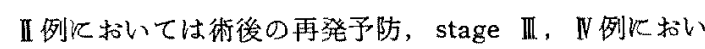
ては寛解維持療法に適していると思われた。

\section{参 考 文 献}

1) Morton $D L$ et al: Immunological factors which influence response to immunotherapy in malignant melanoma. Surgery 68: 158-164, 1970.

2) Falk $R E$ et al: Cell-mediated immunity to human tumors. Ablogation by serum factors and 
nonspecific effects of oral BCG therapy. Arch Surg 107: 261-265, 1973.

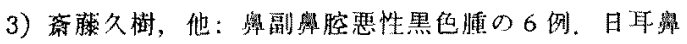
80: 14-27, 1977.

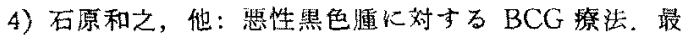
新医学 33: 1528-1536, 1978.

5）野田获夫：晹溶性コーディンタ・カプセルの武慗。 菤局 18: 657-659, 1967.

6) Demopoulas $H B$ : Effects of reducing the phenylalanine-tyrosine intake of patients with advanded malignant melanoma. Cancer 19: 657-664, 1966.

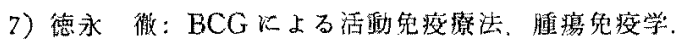

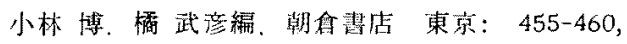
1974.

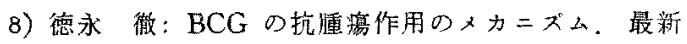
医学 33: 1513-1920, 1978.

9) Sparks $F C$ et al: Complications of BCG immunotherapy in patients with cancer. N Engl J Med 289: 827-830, 1973 .

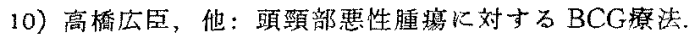
理舞 $22: 481-487,1976$.

11) MasGregor $A$ et al: Oral Bacille Calmette Guérin. Immunostimulation in malignant melanoma. Surg Gynec \& Obstetrics. 141: 747$754,1975$.

12）立石恭子，他：新生胃，乳幼児火対する BCG 経口 投与成結。結模 $39: 371,1964$.

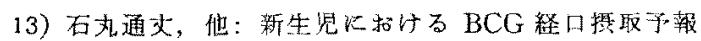
医学之生物学 79: 131-134, 1969.

14)室橋豊穂，他：BCG 経口奜取モルモットに蛙ける 抗結核兒疫。最新医学 $33: 1575,1978$.

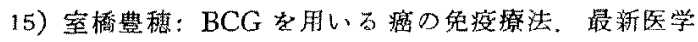
$33: 1505-1506,1978$.

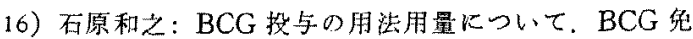
疫療啮誌 $3: 143-151,1979$.

17) 第 3 回 BCG 免疫潦法研究会 綜合討諭(要旨)，最 新医学 33: 1584-1587, 1978.

18）成沢省三，他：BCGカプセルの保存战繶，BCG 绐

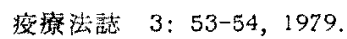

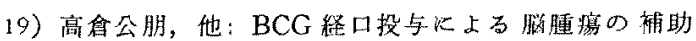

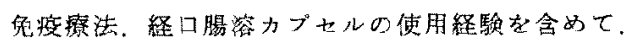

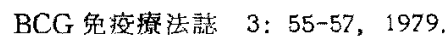

20) MacDonald A $S$ et al: Effects of oral BCG in solid tumors. BCG in cancer immunotherapy. Lamoureux G et al, Grune \& Stratton, New York: 133-138, 1976.

21) Gutterman $J U$ et al: Chemoimmunotherapy of disseminated malignant melanoma with dimethyl triazeno imidazole carboxamide and Bacillus Calmette Guerin. N Engl J Med 291: 592-597, 1974.

22) Mathe $G$ : Surviving in company of BCG. Cancer Immunol Immunother 1: 3-5, 1976.

稿を終るたあたり，BCG腸溶カブセルの作留に際し

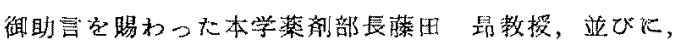
DTICD試用を快諾下さった国立がセンタ一皮成科部

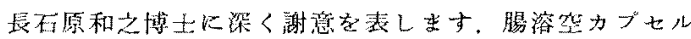

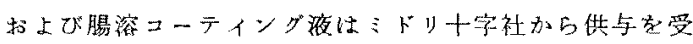
けた。湖せて謝意を婊します。

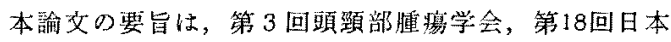

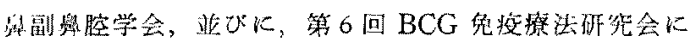
扣いてロ渍した。

（原精受付 昭和55，1，14日）

别殿請求先 036 弘前市在府旷 5

弘前大学医学部耳與咽喉科学教室 斎藤 久樹 